\title{
Growth kinetics of a Vero cells adapted Bangladeshi strain of peste des petits ruminants (PPR) virus in cell culture
}

\author{
Md. Saiful Islam Siddiqui ${ }^{1}\left[\right.$ Dd. Rafiqul Islam ${ }^{2} \cdot$ Emdadul Haque Chowdhury $^{2}$
}

Received: 2 April 2020 / Revised: 30 November 2020 / Accepted: 3 December 2020 / Published online: 5 January 2021

(c) The Author(s), under exclusive licence to Springer-Verlag GmbH, DE part of Springer Nature 2021

\begin{abstract}
Growth kinetics of a Vero cells adapted Bangladeshi strain of peste des petits ruminants virus was studied in Vero cells to determine maximum virus yield. One-step growth curve was formulated after determining virus in both supernatant (CFV) and cell lysate (CAV) at different time categories by microtitre plate titration in Vero cells and the viral presence was confirmed by real-time RT-PCR. The virus was first detected in both the supernatants and cell pellets at 12 hpi. The virus titre reached its plateau at $72 \mathrm{hpi}$. Maximum virus titre of CAV was $6.2 \log _{10} \mathrm{TCID}_{50} / \mathrm{ml}$ and that of CFV was $5.2 \log _{10} \mathrm{TCID}_{50} /$ $\mathrm{ml}$ at $72 \mathrm{hpi}$. After that, the titer gradually declined, but maintained at $4.5 \log _{10} \mathrm{TCID}_{50} / \mathrm{ml}$ in case of CAV and $4.2 \log 10$ $\mathrm{TCID}_{50} / \mathrm{ml}$ in case of CFV at $96 \mathrm{hpi}$. It was concluded that the optimum time point for harvesting Vero cell culture is $72 \mathrm{hpi}$.
\end{abstract}

Keywords Vero cell $\cdot$ PPR virus $\cdot$ Virus titre $\cdot$ Growth curve

\section{Introduction}

Peste des petits ruminants (PPR) virus belongs to genus Morbillivirus under the family Paramyxoviridae, popularly known as Goat plaque of small ruminant as characterized by fever, anorexia, ulcerative necrotic stomatitis, diarrhea, purulent ocular and nasal discharges, pneumonia and respiratory distress, and death (Yongqiang et al. 2015; Chowdhury et al. 2014). Mortality and morbidity may reach up to 90 and

Communicated by Erko Stackebrandt.

Md. Saiful Islam Siddiqui

msisiddiqui2000@yahoo.com

Md. Rafiqul Islam

mrislam@bau.edu.bd

Emdadul Haque Chowdhury

emdad001@ bau.edu.bd

https://

www.researchgate.net/profile/Emdadul_Haque_Chowdhury

https://scholar.google.com/citations?hl=en\&user

$=1 \mathrm{R} 2 \mathrm{qm}$ EAAAAJ

1 Department of Anatomy and Histology, Faculty of Veterinary, Animal and Biomedical Sciences, Sylhet Agricultural University, Sylhet 3100, Bangladesh

2 Department of Pathology, Faculty of Veterinary Science, Bangladesh Agricultural University, Mymensingh 2202, Bangladesh
100\%, respectively (Chowdhury et al. 2014). In Bangladesh, PPR is endemic since 1993. PPR is considered as the major hindrance of goat rearing as economic loss due to PPR in small ruminants 1000 USD annually (DLS 2010). The viral replication occurs in the host cell cytoplasm and the virus is released by budding (Cromeans et al. 1989; Takimoto and Portner, 2004). Virus use the machinery and metabolism of a host cell to produce multiple copies of themselves, and they assemble in the cell (Yin and Redovich 2018), When infected, the host cell is forced to rapidly produce thousands of identical copies of the original virus. However, these mechanisms are not very efficient in the viruses of Paramyxoviridae family and a substantial amount of the produced viruses is kept associated with the host cell membranes. During cell culture, the viral RNA can stay free in the cell and be replicated as such, or it can be incorporated into the host chromosome and be replicated simultaneously with it. Viral proteins are next synthesized with the host's machinery under the direction of viral RNA and the new virus particles are assembled mechanically. These particles can find their way out of the cell or lysate, and be released into the medium, ready to infect new cells (Más and Meloro 2013). It is essential to measure the viral load in both supernatant (cellfree virus-CFV) and cell lysate (cellassociated virus-CAV).

To reduce the burden due to PPR an effective, potent vaccine production is essential; therefore, adaptation of virus 
in cell culture, viral replication, as well as high virus yield are equally important in vaccine production strategy. Classic study of this kind defined the one-step growth curve, in which cells in a culture are infected simultaneously using a high multiplicity of infection and the increase in infection virus over time is followed by sequential sampling and titration. Virus that is free in the medium can be titrated separately from viruses that remain in cell lysate (Frederick et al. 1999).

The titre of PPR virus increases significantly if the virus is passaged in Vero cells serially. Adaptation of PPR virus on Vero cells may be suitable for large-scale production of antigen. The field isolates of PPRV could be passaged in Vero monolayer cell culture, which showed characteristic CPE and were readily adapted between 5 and 7 th passages. The CPE usually develops within $48 \mathrm{~h}$. Production of PPRV vaccine in tissue culture is widely used all over the world. To get maximum yield of virus, which is essential for potent vaccine formulation, the virus has to be harvested at the proper time following cell infection. To determine such optimum time, the growth curve of the virus in infected tissue culture, the development of complement-fixing antigen has to be studied. Therefore, the present study was designed to determine the multiplication profile of infectious viral particles in PPR-infected Vero cells at 60th passage level.

\section{Materials and methods}

\section{Place of work}

The research work was done at Gene laboratory and Cell culture and Virology laboratory. of the Department of Pathology, Faculty of Veterinary Science, Bangladesh Agricultural University, Bangladesh.

\section{Virus}

Locally isolated Bangladeshi strain of peste des petits ruminants (PPR) virus (BD/PPR/08) had been attenuated by 60 serial passages in Vero cell culture was used in this study.

\section{Tissue cultures}

Vero cells (CLS, Germany; order no. 605372) were brought and used in this study.

\section{Cell culture media and reagents}

Cell culture medium-M-199 (Gibco-Invitrogen, cat no. 11825 ) and calf serum-FBS (Gibco-Invitrogen, cat no. 10437) were used for culture and maintenance of Vero cells. Cell culture working medium was made by adding
L-glutamine, HEPES buffer, Sodi-bi-carb, antifungal solution (Fungizone), antibiotic (gentamicin), and distilled water with commercially available M-199 solution. $0.25 \%$ Trypsin with EDTA (Gibco-Life technologies 20,367, C13) were used in this study for dissociation and detachment of cells from cell culture flask during subculture.

\section{Growth curve design}

Cells were grown to approximately $90 \%$ confluency in petridish (Nunc, Denmark) and infected with PPRV at a fixed multiplicity of infection (MOI) of 0.01. All petridishes are marked and grouped into different time category e.g., $12,24,36 \ldots 96 \mathrm{~h}$. After incubation at $37^{\circ} \mathrm{C}$ for $1 \mathrm{~h}$ with rocking every $10 \mathrm{~min}$, the virus suspension was discarded and cells were washed thrice with $1 \mathrm{x}$ phosphate-buffered saline (PBS) to remove unadsorbed virus. The end of the adsorption period was considered zero time of post-infection (p.i.). Cells were fed with M-199 containing 5\% FBS and returned to the incubator. Cell lysate (CAV) and corresponding supernatants were harvested at different time interval as described below. The medium from one petridish, selected randomly, was harvested using a pipette and stored immediately at $-70^{\circ} \mathrm{C}$ as cell-free virus (CFV). Attached cells from the petridish were harvested with a cell scraper (Nunc, Denmark), washed four times with 1x PBS, and suspended in $1.0 \mathrm{ml} \mathrm{M-199}$ supplemented with 5\% FBS. The cell suspension was freeze-thawed thrice, centrifuged at $2790 \times \mathrm{g}$ for $10 \mathrm{~min}$, discard supernatant, and stored the cell suspension at $-70{ }^{\circ} \mathrm{C}$ as cell lysate or cellassociated virus (CAV). The same procedure was followed for all the subsequent samples.

\section{Infectivity titration}

After completion of the experiment, samples (both CFV and CAV) were thawed at $4{ }^{\circ} \mathrm{C}$, diluted serially (tenfold dilution), and titrated in Vero cells. Cells were observed daily for $\mathrm{CPE}$ and $50 \%$ tissue culture infective dose $\left(\mathrm{TCID}_{50} / \mathrm{ml}\right)$ was determined by microtitre assay as described by Reed and Muench (1938)

\section{Confirmation of PPR viral RNA by real-time RT-PCR}

The presence of virus in the harvested samples (both CFV and CAV) was first confirmed by real-time RT-PCR. For this, one-Step RevTrans-qRT-PCR Evagreen (No Rox) kit (Bio sell Inc., Germany) and AB 7500 Fast Real Time PCR were used. Briefly, the methods of real-time RT-PCR was as follows-

Syber green real-time RT-PCR for F\& N genes were performed in AB 7500 Fast Real-Time PCR Machine using One-Step RevTrans-qRT-PCR Evagreen (No Rox) kit (Bio Sell, Germany). PPRV F1b, PPRV F2d primer for F gene 
and $\mathrm{NP}_{3}$ and $\mathrm{NP}_{4}$ primer for $\mathrm{N}$ gene were used in this study (Ozkul 2002; Couacy-Hymann et al. 2002) The master mix for syber green real-time RT-PCR was prepared as reaction volume $25.0 \mu \mathrm{l}$ comprising of both forward and reverse primer (100 pmol/ $\mu \mathrm{l}) 1.0 \mu \mathrm{l}, 2 \mathrm{X}$ RT-qPCR EvGr-Reaction Mix $12.5 \mu \mathrm{l}$, Rnase free water $8.5 \mu \mathrm{l}$, and template RNA $2.0 \mu 1$.

The syber green real-time RT-PCR was performed in MicroAmp Optical Fast $0.1 \mathrm{ml}$ 8-tube strips. First, $20 \mu \mathrm{l}$ master mix was dispensed to each tube of the strip. Then, $5 \mu \mathrm{l}$ RA of the samples, positive control, and negative control was added to respective wells and mixed with the help of pipette tips. The tubes were closed with cap strip and the tube strip was placed to the tube rack in the machine. The optical setting was selected for syber green detection and the test was run with the preset thermal profile includes reverse transcription stage at $50{ }^{\circ} \mathrm{C}$ for $15 \mathrm{~min}$, Initial denaturation at $95^{\circ} \mathrm{C}$ for $5 \mathrm{~min}$ and 40 cycles of PCR (denaturation at $95^{\circ} \mathrm{C}$ for $15 \mathrm{~s}$, annealing at $60^{\circ} \mathrm{C}$ for $20 \mathrm{~s}$, and extension at $72^{\circ} \mathrm{C}$ for $30 \mathrm{~s}$ ). The results were presented as the $C_{\mathrm{t}}$ value for each sample, which was determined from the amplification plot.

\section{Results}

One-step growth curve was performed on Vero cells to determine the growth characteristics of the PPRV isolates. One-step growth curve is a plot typical of the rapid growth of a virus in cell culture when all cells are infected simultaneously. Released (supernatant or extracellular virus or cellfree virus-CFV) and lysates or cellassociated viruses (CAV) were harvested at different time intervals in between 12 and 96 hpi and their titres were determined. Viruses were detected in both culture supernatants and cell lysates at 12 hpi. The latent phase in both lysates and supernatant was found short, but the exponential phase was rapid because of using Vero cell adapted PPRV tissue culture fluid, i.e., 60th passaged PPR virus tissue culture fluid (PPRV- TCF) used in growth curve study (Fig. 1).

The multiplication profile of infectious viral particles in PPR-infected Vero cells at 60th passage level was determined by growth kinetics. Figure 1 shows the virus growth pattern in the supernatant and cell lysate. Maximum virus titre observed in the lysates or cell pellet, i.e., cellassociated virus (CAV) was $6.2 \log _{10} \mathrm{TCID}_{50} / \mathrm{ml}$ and in supernatant, i.e., cellfree virus (CFV) was $5.2 \log _{10} \mathrm{TCID}_{50} / \mathrm{ml}$ on $72 \mathrm{hpi}$ of 60th passage level, respectively. In this study, an increase in virus yield from $12 \mathrm{hpi}$ to $72 \mathrm{hpi}$, with a maximum titer of $6.2 \log _{10} \mathrm{TCID}_{50} / \mathrm{ml}$ was observed on $72 \mathrm{hpi}$, and beyond which the titer did not increase but was maintained as 4.5 $\log _{10} \mathrm{TCID}_{50} / \mathrm{ml}$ up to $96 \mathrm{~h}$ of observation in case of lysates (Fig. 1), and in case of supernatant, it was maintained as 4.2 $\log _{10} \mathrm{TCID}_{50} / \mathrm{ml}$ up to $96 \mathrm{hpi}$.

The commencement of CPE in Vero cell lines was observed at $12 \mathrm{hpi}$ at 60th passage level and the pattern of induction of CPE resembled that observed in previous passages. The CPE was characterized by rounding, ballooning of cells followed by foci or small syncytia. During later
Fig. 1 Maximum PPRV titre was achieved at $72 \mathrm{~h}$ post-inoculation with both cell lysates (CAV) and supernatant (CFV). Here, $C A V$ cell lysates/cells associated virus, $C F V$ supernatant/cellfree virus, and hpi hour of post-infection

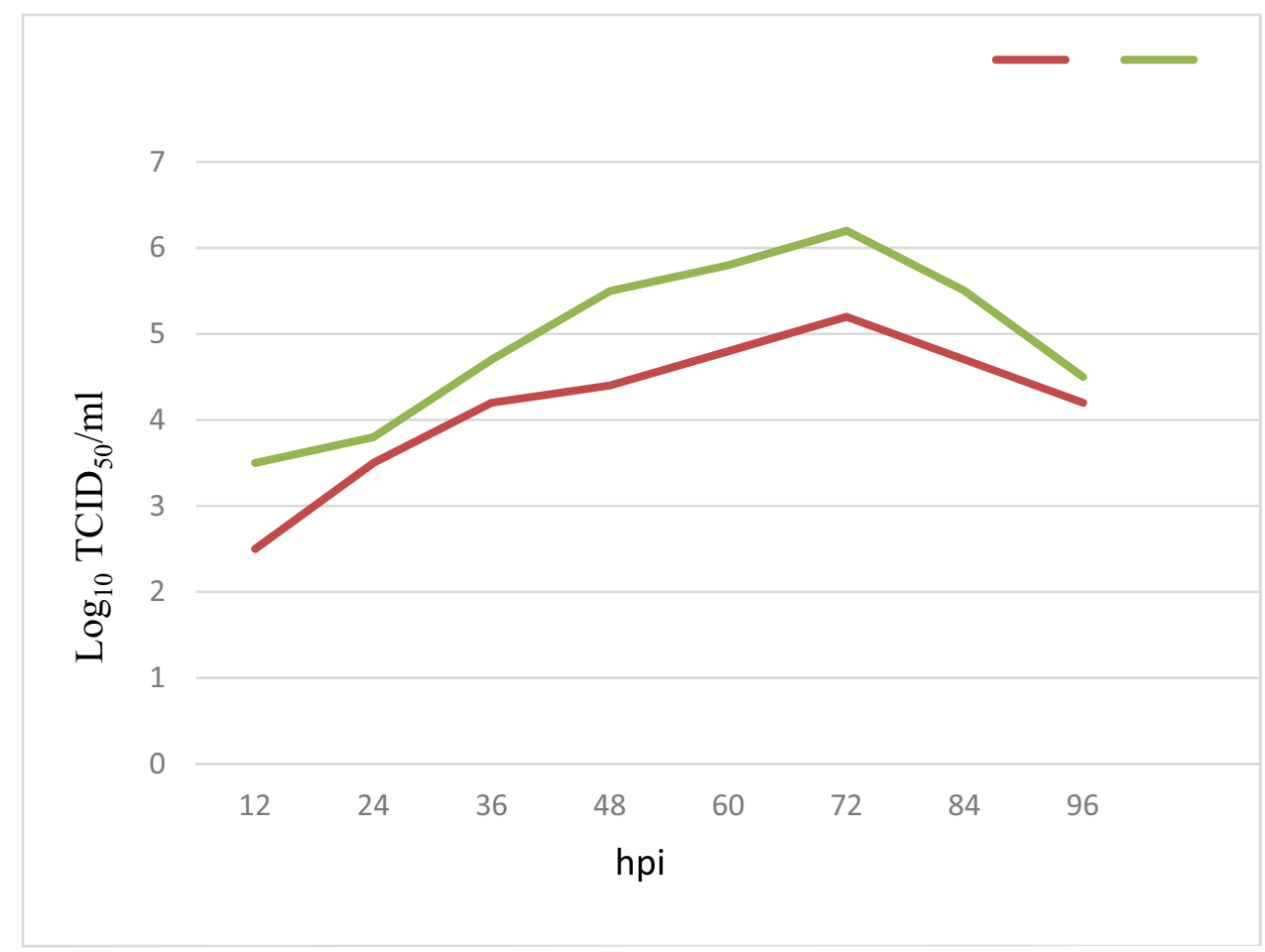


stage, large syncytia formation and disintegration of cells leading to total detachment of cells monolayer were found. 100\% CPE was achieved at $72 \mathrm{hpi}$.

A real-time RT-PCR method was applied to estimate the presence of PPRV during 12-96 hpi (Fig. 2a, b). Melting curve was considered in real-time RT-PCR results. Minimum $C_{\mathrm{t}}$ value observed in the cell lysates or pellet, i.e., cellassociated virus (CAV) was 17.88 and in supernatant, i.e., cellfree virus (CFV) was 18.77 on 72 hpi of 60th passage level. In this study, a decrease in $C_{\mathrm{t}}$ value from 12 to 72 hpi was observed and beyond, which the $\mathrm{Ct}$ values did not decrease, would rather increase up to $25.05 / 25.74$. $C_{\mathrm{t}}$ values with corresponding titres of all time categories of hpi for both supernatant and cell lysate in growth kinetics study are shown in Table 1.

Here, S1: 60th passage tissue culture fluid (TCF) of isolate BD_PPR_08, S2: cell lysate at 72 hpi, S3: cell lysate at $60 \mathrm{hpi}$, S4: tissue culture supernatant of 60th passage of isolate BD_PPR_08, S5: cell lysate at $84 \mathrm{hpi}$, S6: cell lysate at 48 hpi, S7: supernatant at 48 hpi, NC: threshold line, PC: positive control.

Here, S1: supernatant at $96 \mathrm{hpi,} \mathrm{S2:} \mathrm{supernatant} \mathrm{at} 12$ hpi, S3: supernatant at $72 \mathrm{hpi,} \mathrm{S4:} \mathrm{supernatant} \mathrm{at} 24 \mathrm{hpi,} \mathrm{S5:}$ supernatant at $24 \mathrm{hpi}, \mathrm{S} 6$ : cell lysate at $36 \mathrm{hpi}, \mathrm{S} 7$ : supernatant at 84 hpi, S8: supernatant at $60 \mathrm{hpi,} \mathrm{S9:} \mathrm{cell} \mathrm{lysate} \mathrm{at}$ 96 hpi, S10: supernatant at 36 hpi, NC: threshold line, PC: positive control.

\section{Discussion}

To determine the proper time at which the harvested virus could contain the required amount of intact virus to produce a good and potent vaccine, maximum virus titer, the commencement of CPE, pattern of induction of CPE, the virus growth kinetics are still desirable (Jadi et al. 2010). A high virus yielding host system is equally important in large-scale propagation of viruses for diagnostic and vaccine development studies. In this study, single or one-step growth curves were undertaken on Vero cells to determine the growth characteristics of PPR viruses. Released (supernatant or extracellular virus or cellfree virus-CFV) and cell lysate virus or cellassociated viruses (CAV) were harvested at 12-96 hpi and their titers were determined. Viruses were detected in both the supernatant and cell lysate in 12 hpi. The latent phase or stages in both supernatant (CFV) and cell lysate (CAV) were found short, but the exponential phase is rapid. This might be due to using Vero cell adapted PPRV, i.e., 60th passaged PPRV-TCF in growth curve study. On assay of the supernatant and cell extract collected at different time intervals as described above, a slow increasing pattern of PPR virus titre in culture supernatant was observed during the first $18 \mathrm{~h}$ of growth cycle (eclipse phase of virus multiplication was short as Vero cells adapted virus were used). The cellfree virus (CFV) gradually increased after $12 \mathrm{~h}$ and a maximum virus titre was achieved around 3 days ( $72 \mathrm{hpi}$ ), and it was $5.2 \log _{10} \mathrm{TCID}_{50} / \mathrm{ml}$ at $72 \mathrm{hpi}$. Virus could be detected between 12 and $18 \mathrm{~h}$ in cell lysate, and a maximum virus titre was achieved around 3 days (72 hpi) and it was $6.2 \log _{10} \mathrm{TCID}_{50} / \mathrm{ml}$. Subsequently, the titre of cell lysate virus or intracellular or cellassociated virus (CAV) was always somewhat higher than that of the virus in supernatant, i.e., cellfree virus (CFV) during the entire phase virus of active replication of the virus (between 2 and 3 days) followed by a plateau. All the findings were found related closely to the findings of multistep growth kinetics study of two isolates of 5th passage level PPRV (PPRIzatnagar/94 and PPR Sungri/96) in Vero and Marmoset B95a cells or B lymphoblastoid cells at an MOI of 0.001 by Sreenivasa et al. (2006).

The replication kinetics and CPE development of viruses were found to depends upon the several factors such as (i) cell line used, (ii) the passage level or adaptation level, and (iii) method of selection of the virus population. The growth kinetics study of Vero cells adapted PPR virus in this study (at 60th passage level) revealed that the titres were $5.5 \log _{10} \mathrm{TCID}_{50} / \mathrm{ml}$ on $48 \mathrm{hpi}$ in case of cell lysate and $5.2 \log _{10} \mathrm{TCID}_{50} / \mathrm{ml}$ on $72 \mathrm{hpi}$ in case of supernatant. Both findings were found in accordance with the findings of Chandrahas et al., 2014 at $3^{\text {rd }}$ passage level where titre of tissue culture fluid ranges 3.5-4.5 $\log _{10} \mathrm{TCID}_{50} / \mathrm{ml}$. In this study, the titre for cell lysate or cellassociated virus (CAV) reached $5.5 \log _{10}$ TCID $_{50} /$ $\mathrm{ml}$ and for released virus or supernatant or cellfree virus (CFV) $4.7 \log _{10} \mathrm{TCID}_{50} / \mathrm{ml}$ on 84 hpi which were closely related the titre found in a study (Leonard et al. 2008) in regard to growth dynamics of another morbillivirus; measles virus in Vero/hSLAM cells which were $5.0 \log _{10}$ $\mathrm{TCID}_{50} / \mathrm{ml}$ on $84 \mathrm{hpi}$ and $4.0 \log _{10} \mathrm{TCID}_{50} / \mathrm{ml}$ on $108 \mathrm{hpi}$ in case of cell lysate and supernatant respectively, though titres on 108 hpi in case of supernatant were not measured in this study. The titre observed in this study was found similar to the titre produced by the measles virus in Vero cells in another study which was approximately $5.0 \log 10$ $\mathrm{TCID}_{50} / \mathrm{ml}$ on day 4 of pi. at an MOI 0.01 (Takeuchi et al. 2002). In this study, it showed an increase in virus yield from 12 to $72 \mathrm{hpi}$, with a maximum titer observed at 72 hpi, and beyond which the titer did not increase. This finding was found close to the findings of Matumoto (1966) who first noted a rise in titer at $20 \mathrm{hpi}$, and the maximal titer was reached in 2-4 days post-infection (dpi) by measles virus in Monkey kidney cells and in 4 dpi by the same virus in Vero cells (Takeuchi et al. 2002) at an MOI 0.01. The infective titre of cell lysate virus in the culture increases more rapidly, is always much higher, and reaches a plateau earlier, than that in the fluid phase. 
Fig. 2 a Confirmation of PPRV in both cell lysates and supernatant by real-time RT-PCR at different time categories. b: Confirmation of PPRV in both cell lysates and supernatant by real-time RT-PCR at different time categories

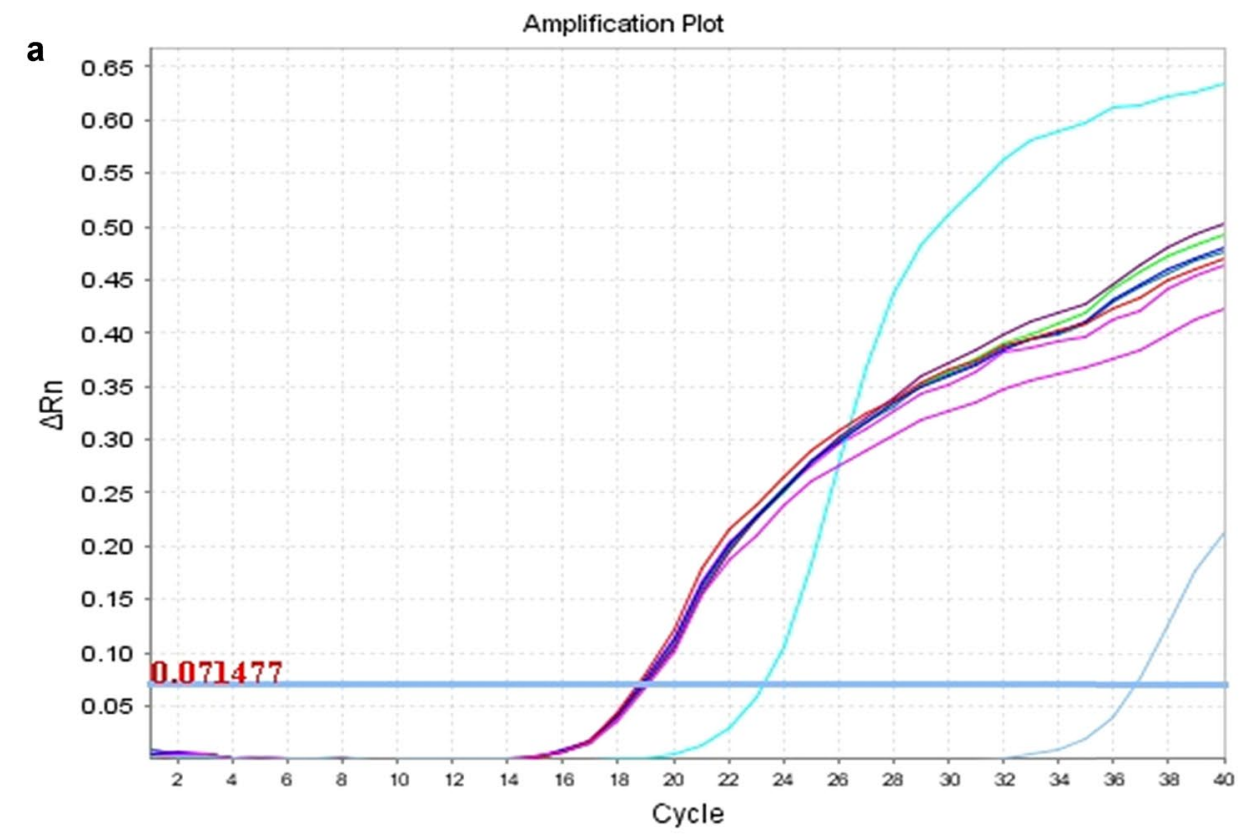

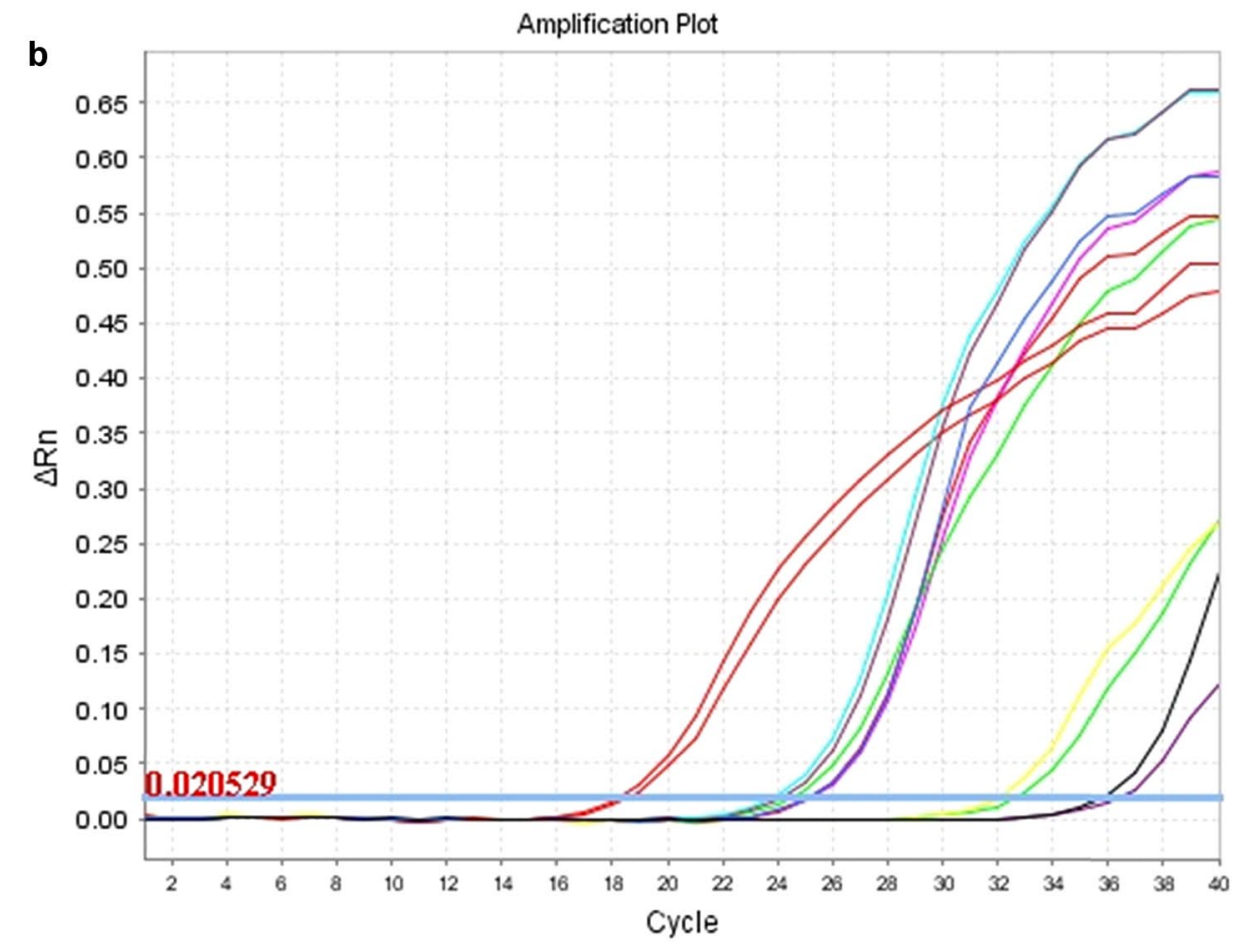

53

S10

S4

55

S6

s7

$\mathrm{s} 8$

59

$\mathrm{S2} \square \mathrm{S1} \square \mathrm{NC} \square \mathrm{PC}$ 
Table $1 \mathrm{C}_{\mathrm{t}}$ values with corresponding titres of all time categories of hpi

\begin{tabular}{|c|c|c|c|c|c|c|}
\hline \multirow{3}{*}{$\begin{array}{l}\text { Time elapsed } \\
\text { after cell infection } \\
\text { (h) } \\
\text { Aspect of devel- } \\
\text { opment }\end{array}$} & \multicolumn{6}{|l|}{ Virus titer } \\
\hline & \multicolumn{3}{|c|}{ Supernatant (C.F.V) } & \multicolumn{3}{|c|}{ Cell lysate (CAV) } \\
\hline & $\begin{array}{l}\text { Titre } \\
\left(\mathrm{TCID}_{50 / \mathrm{ml}}\right)\end{array}$ & $\begin{array}{l}\text { Real-time } \\
\text { RT-PCR } C_{\mathrm{t}} \\
\text { value }\end{array}$ & Sample & $\begin{array}{l}\text { Titre } \\
\left(\mathrm{TCID}_{50 / \mathrm{ml}}\right)\end{array}$ & $\begin{array}{l}\text { Real-time } \\
\text { RT-PCR } \\
C_{\mathrm{t}} \text { value }\end{array}$ & Sample \\
\hline 12 & 2.5 & 36.78 & $\mathrm{CFV}$ at $12 \mathrm{hpi}$ & 3.5 & 33.17 & CAV at $12 \mathrm{hpi}$ \\
\hline 24 & 3.5 & 33.17 & $\mathrm{CFV}$ at $24 \mathrm{hpi}$ & 3.8 & 32.55 & $\mathrm{CAV}$ at $24 \mathrm{hpi}$ \\
\hline 36 & 4.2 & 25.77 & $\mathrm{CFV}$ at $36 \mathrm{hpi}$ & 4.7 & 24.68 & CAV at 36 hpi \\
\hline 48 & 4.4 & 25.47 & $\mathrm{CFV}$ at $48 \mathrm{hpi}$ & 5.5 & 18.05 & CAV at 48 hpi \\
\hline 60 & 4.8 & 19.09 & $\mathrm{CFV}$ at $60 \mathrm{hpi}$ & 5.8 & 17.92 & $\mathrm{CAV}$ at $60 \mathrm{hpi}$ \\
\hline 72 & 5.2 & 18.77 & $\mathrm{CFV}$ at $72 \mathrm{hpi}$ & 6.2 & 17.88 & $\mathrm{CAV}$ at $72 \mathrm{hpi}$ \\
\hline 84 & 4.7 & 24.37 & CFV at 84 hpi & 5.5 & 18.07 & CAV at $84 \mathrm{hpi}$ \\
\hline 96 & 4.2 & 25.74 & CFV at 96 hpi & 4.5 & 25.05 & CAV at $96 \mathrm{hpi}$ \\
\hline
\end{tabular}

$C F V$ supernatant/cellfree virus, $C A V$ cell lysate/cellassociated virus, $h p i$ hours of post-infection
The infective titres in both cells and fluid show increasingly earlier rise and greater rates of increase, and reach plateaus earlier, as the input multiplicity increases. This finding was in agreement with the research findings of other morbilli viruses as measles virus in Monkey kidney cell culture (Matumoto 1966), in mouse-derived cell cultures (Kohno et al. 1968).

Growth curve analysis of recombinant rinderpest virus (RPVs) containing chimeric $\mathrm{H}$ proteins was conducted by Parida et al. (2006) where Vero cells were infected with viruses such as RPV2C, PPRV, or RPV2C-PPRTm (at MOI 0.1) or virus RPV2C-PPRExt (at MOI 0.01), and the same titre was found on $72 \mathrm{hpi}$ which was 3.5 $\log 10$ TCID $_{50} / \mathrm{ml}$. Marmoset B95a and Vero-SLAM cells were infected simultaneously with two rinderpest virus and titres were found between $5.0 \log 10 \mathrm{TCID}_{50} / \mathrm{ml}$ and $6.0 \log 10 \mathrm{TCID}_{50} / \mathrm{ml}$ by 96 hpi (Banyard et al. 2010). In another study of rinderpest virus growth profile conducted by Nores and McCullough (1997) observed, the highest virus titres were obtained with the RPV-Saudi isolate at $10 \mathrm{dpi}$. in infected bovine monocytes. In another study by Aravind et al. (2015), the multiplication profile of infectious viral particles in Duck enteritis virus (DEV) infected Vero cells at 15th passage level was determined by growth kinetics. In that study, it showed an increase in virus yield from 6 to $48 \mathrm{hpi}$. with a maximum titer of $5.6 \log 10 \mathrm{TCID}_{50} / \mathrm{ml}$ observed at $48 \mathrm{hpi}$, and beyond which the titer did not increase, but was maintained as $4.0 \log 10 \mathrm{TCID}_{50} / \mathrm{ml}$ up to $96 \mathrm{~h}$ of observation (Aravind et al. 2015). In growth kinetics study of Chandipura virus using Vero E6 cell line, maximum virus titre observed in the Vero cell pellet was $10^{4.0} \mathrm{TCID}_{50} / \mathrm{ml}$ at $6 \mathrm{hpi}$ and in supernatant was $6.0 \log 10 \mathrm{TCID}_{50} / \mathrm{ml}$ at $9 \mathrm{hpi}$. In this study, maximum titre was found on $72 \mathrm{hpi}$ and more titre was found in cell lysate (CAV) than supernatant (CFV). Based on these, to get maximum virus yield, cell lysate
(CAV) along with supernatant (CFV) could be harvested on 72 hpi.

\section{Conclusion}

It has been concluded that, in this study, attenuated PPR virus in Vero cells showed high titre of progeny virus on $72 \mathrm{~h}$ of pi which could be the appropriate time of harvesting infected tissue culture fluid during production of an effective, potent vaccine.

Acknowledgements The Bangladesh Agricultural Research Council (BARC), Ministry of Agriculture, Government of the Peoples Republic of Bangladesh [grant numbers SPGR-360, NATPPhase-1, BARC], supported this work.

Author contributions This research was conducted under the direct supervision of the two co-authors where they played role as Supervisor and Co-supervisor, respectively, of the $\mathrm{PhD}$ research of the corresponding author.

Funding The Bangladesh Agricultural Research Council (BARC), Ministry of Agriculture, Government of the Peoples Republic of Bangladesh [grant numbers SPGR-360, NATPPhase-1, BARC], supported this work.

Availability of data and materials Available on request.

\section{Compliance with ethical standards}

Conflicts of interest/competing interests No conflict of interest.

\section{References}

Aravind S, Kamble NM, Gaikwad SS, Shukla SK, Dey S, Mohan CM (2015) Adaptation and growth kinetics study of an Indian 
isolate of virulent duck enteritis virus in Vero cells. Microb Path 78:14-19. https://doi.org/10.1016/j.micpath.2014.11.008

Banyard AC, Simpson J, Monaghan P, Barrett T (2010) Rinderpest virus expressing enhanced green fluorescent protein as a separate transcription unit retains pathogenicity for cattle. J General Virol 91:2918-2927. https://doi.org/10.1099/vir.0.023598-0

Chandrahas S, Arnab S, Kaushal K, Rajkumar R, BharatSingh S, Harshad CC (2014) Comparative analysis of peste des petits ruminantsvirus tropism in Vero and Vero/SLAM cells. J Appl Ani Res 42(3):366-369. https://doi.org/10.1080/09712119.2013.875900

Chowdhury EH, Bhuiyan AR, Rahman MM, Siddique MSA, Islam MR (2014) Natural PPR virus infection in Black bengal goat: virological, pathological and immuno-histochemical investigations. BMC Vet Res 10:263. https://doi.org/10.1186/s12917-014-0263-y

Couacy-Hymann E, Roger F, Hurard C, Guillou JP, Libeau G, Diallo A (2002) Rapid and sensitive detection of peste des petits ruminants virus by a polymerase chain reaction assay. Journal of Virological Methods 100(1-2):17-25

Cromeans T, Fields HA, Sobsey MD (1989) Replication kinetics and cytopathic effect of Hepatitis A virus. J Gen Virol 70:2051-2062

DLS (2010) Problems and prospects of goat rearing in Bangladesh. p 77. Proceedings of the Annual Scientific Workshop of the Department of Livestock Services (DLS), Ministry of Livestock and Fisheries, Govt. of the Peoples Republic of Bangladesh

Frederick A, Murphy E, Paul J, Gibbs MC, Horzinek MJS (1999) Text of veterinary virology, 3rd Edition. Academic press. Viral replication. Chapter p: 43-59. www.microbiologyresearch.org by IP: 180.211.162.38. On: Thu, 10 Mar 2016 15:06:04. Accessed 10 Mar 2016

Jadi RS, Sudeep AB, Kumar S, Arankalle VA, Mishra AC (2010) Chandipura virus growth kinetics in vertebrate cell lines, insect cell lines \& embryonated eggs. Indian J Med Res 132:155-159

Kohno S, Kohase M, Suganuma M (1968) Growth of measles virus in a mouse derived established cell line L cells. Japan J Med Sci Biol 21:301-311

Leonard VHJ, Sinn PL, Hodge G, Miest T, Devaux P, Oezguen N, Braun W, McCray PB, Jr, McChesney MB, Cattaneo R (2008) Measles virus blind to its epithelial cell receptor remains virulent in rhesus monkeys but cannot cross the airway epithelium and is not shed. J Clin Invest 118(7): 2448. http://www.jci.org. https:// doi.org/10.1172/JCI35454. Accessed 20 June 2008

Más V, Melero JA (2013) "Entry of enveloped viruses into host cells: membrane fusion". Structure and physics of viruses. Subcell Biochem 68:467-487. https://doi.org/10.1007/978-94-007-65528_16.ISBN978-94-007-6551-1.PMC7121288.PMID23737062
Matumoto M (1966) Multiplication of Measles Virus in Cell Cultures. Bacteriol Reviews 30(1):152-176

Nores JER, McCullough KC (1997) Rinderpest virus isolates of different virulence vary in their capacity to infect bovine monocytes and macrophages. J Gener Virol 78:1875-1884. https://doi. org/10.1099/0022-1317-78-8-1875

Ozkul A, Akca Y, Alkan F, Barrett T, Karaoglu T, Dagalp SB, Anderson J, Yesilbag K, Cokcaliskan C, Gencay A, Burgu I (2002) Prevalence, Distribution, and Host Range of Peste des petits ruminants virus. Turkey. Emerging Infectious Diseases 8(7):708-712

Parida S, Mahapatra M, Hawes P, Baron MD, Monaghan P, Barrett $T$ (2006) Importance of the extracellular and cytoplasmic/transmembranedomains of the haemagglutinin protein of rinderpest virus for recovery of viable virus from cDNA copies. Virus Res 117:273-282. https://doi.org/10.1016/j.virusres.2005.10.022

Reed LJ, Muench H (1938) A simple method of estimating fifty per cent endpoints. Am J Hygiene 27:493-497. https://doi. org/10.1093/oxfordjournals.aje.a118408

Sreenivasa BP, Singh RP, Mondal B, Ghar P, Bandyopadhay SK (2006) Marmost B95 a cells: a sensitive system for cultivation of PPR virus. Vet. Res Commu 30:103-108. https://doi.org/10.1007/ s11259-005-3200-5

Takeuchi K, Takeda M, Miyajima N, Kobune F, Tanabayashi K, Tashiro M (2002) Recombinant wild-type and edmonston strain measles viruses bearing heterologous $\mathrm{H}$ proteins: role of $\mathrm{H}$ protein in cell fusion and host cell specificity. J Virol 76(10):4891-4900. https://doi.org/10.1128/JVI.76.10.4891-4900.2002

Takimoto T, Portner A (2004) Molecular mechanism of paramyxovirus budding. Virus res 106:133-145

Yin J, Redovich J (2018) Kinetic modeling of virus growth in cells. Microbiol Mol Biol Rev MMBR. https://doi.org/10.1128/ MMBR.00066-17 ((PMC 5968458. PMID 29592895))

Yongqiang Z, Xiaodong W, Yanli Z, Jingyue B, Xiaozhen WZW (2015) Isolation and growth characteristics study of a peste des petits ruminants virus isolate from xinjiang. In: National Research Center for Exotic Animal Diseases/China Animal Health and Epidemiology Center. China Ani Health Insp. 2015-10

Publisher's Note Springer Nature remains neutral with regard to jurisdictional claims in published maps and institutional affiliations. 